\title{
New magnetic anomalies of the Outer Capathians in NE Slovakia and their relationship to the Carpathian Conductivity Zone
}

\author{
L'udovít KUCHARIČ ${ }^{1, *}$, Vladimír BEZÁK ${ }^{2}$, Peter KUBEŠ ${ }^{1}$, Vlastimil KONEČNÝ ${ }^{1}$ and Ján VOZÁR ${ }^{2}$ \\ 1 State Geological Institute of Dionýz Štúr, Bratislava, Mlynská dolina 1, 81704 Bratislava, Slovakia \\ 2 Geophysical Institute of the Slovak Academy of Sciences, Dúbravská cesta 9, 84528 Bratislava, Slovakia
}

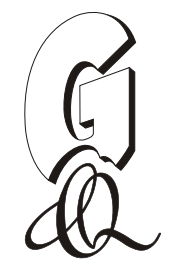

\begin{abstract}
Kucharič L., Bezák V., Kubeš P., Konečný V. and Vozár J. (2013) New magnetic anomalies of the Outer Capathians in NE Slovakia and their relationship to the Carpathian Conductivity Zone. Geological Quarterly, 57 (1): 123-134, doi: 10.7306/gq.1079

Hitherto unknown magnetic anomalies have been detected while assembling a magnetic picture of the Slovakian territory. An impressive magnetic anomaly was recognized in the northeasternmost part of Slovakia associated with sedimentary rocks of the flysch belt. This is a rare phenomenon, because the flysch sequence in Slovakia typically lacks magnetic rocks. Thus, an igneous body intruded into the flysch might cause the anomaly. The shape and the character of the anomalous body suggests that its source is located at shallow depth beneath the surface. The anomaly has been modelled in 2D space. It is interpreted as a Neogene volcanic neck made of intermediate rocks. Such an interpretation is supported by results of thermometric investigation of fluid inclusions, vitrinite reflectance and fission tracks. Further minor anomalies within this area, might also be caused by small near these subvolcanic bodies. The Carpathian Conductivity Zone is located near these new observed magnetic anomalies, which therefore provide a new view on the importance of this zone. The region as a result may have potential for metalogenesis, underground storage of carbon dioxide, and hydrocarbons.
\end{abstract}

Key words: Western Carpathians, flysch belt, magnetic anomalies, Neogene subvolcanic bodies, Carpathian Conductivity Zone.

\section{INTRODUCTION}

The Western Carpathians represent a complicated mountains range, which consists of various tectonic units and blocks (e.g., Bezák et al., 2011). The basic partition into Outer and Inner Carpathians reflects Neoalpine tectonic evolution during the Neogene when the collision of the Inner Carpathian Block with the European Platform formed the Outer Carpathian Flysch Belt. The Pieniny Klippen Belt (PKB) makes up the boundary between the Outer and Inner Carpathians.

The Inner Western Carpathians represent a Palaeoalpine (Cretaceous) nappe system of Paleozoic and Mesozoic rock complexes and superimposed younger sedimentary deposits and large Neogene volcanic fields. The Outer Carpathians represent a Neoalpine (mostly Neogene) nappe system of Jurassic-Paleogene flysch deposits where Neogene volcanic rocks are rare. There are separate intrusive bodies such as dikes, sills, and laccoliths extending from Moravia (Krejčí and Poul, 2010) to southern Poland in the Pieniny area (Birkenmajer et al., 2004; Birkenmajer and Lorenz, 2008) and continuing to Ukraine and Romania (Pécskay et al., 2009; Fig. 1). Mišík (1992) described multiple small occurrences of intermediary

\footnotetext{
* Corresponding author: ludovit.kucharic@geology.sk
}

Received: February 1, 2012; accepted: November 6, 2012; first published online: March 15, 2013
Neogene volcanic rocks (dykes) in the western and the eastern part of the PKB. Besides this, there are local occurrences of Jurassic-Cretaceous volcanic rocks (e.g., Golonka, 2004).

Sequences of Carpathian flysch (Slovakian part) have for decades been considered as rock successsions without any significant magnetic properties creating monotonous and smooth pictures of the Earth magnetic field observed above areas where these rocks are developed (Ondra and Hanák, 1989). From the geomorphological point of view, the area is located in the Bukovské vrchy hills, very close to state boundaries with Poland and Ukraine (Fig. 2). New magnetic measurements have been carried out in the last few years (Kubeš et al., 2008) in the area situated within the Dukla Unit of the Outer Carpathian Flysch Belt in NE Slovakia. The results of these measurements revealed some interesting new features of the Earth's magnetic field which are not typical for the flysch rocks. Part of the magnetic map of NE Slovakia (Kubeš et al., 2008) is shown in Figure 3. The map is mainly characterized by a typical of low intensity magnetic field. The only exceptions are in the easternmost part of Slovakia, where one may distinguish an impressive negative anomaly that is almost concentric in shape and two diminutive positive anomalies (more extensive anomalies located in the S and SE part of the picture related to Neogene volcanic rocks on the surface within the Inner Carpathians).

On current knowledge this magnetic anomalies cannot be to assigned to any lithostratigraphical member of the flysch sequence. The largest anomaly of this area (the negative one) has been modelled in 2D space. 


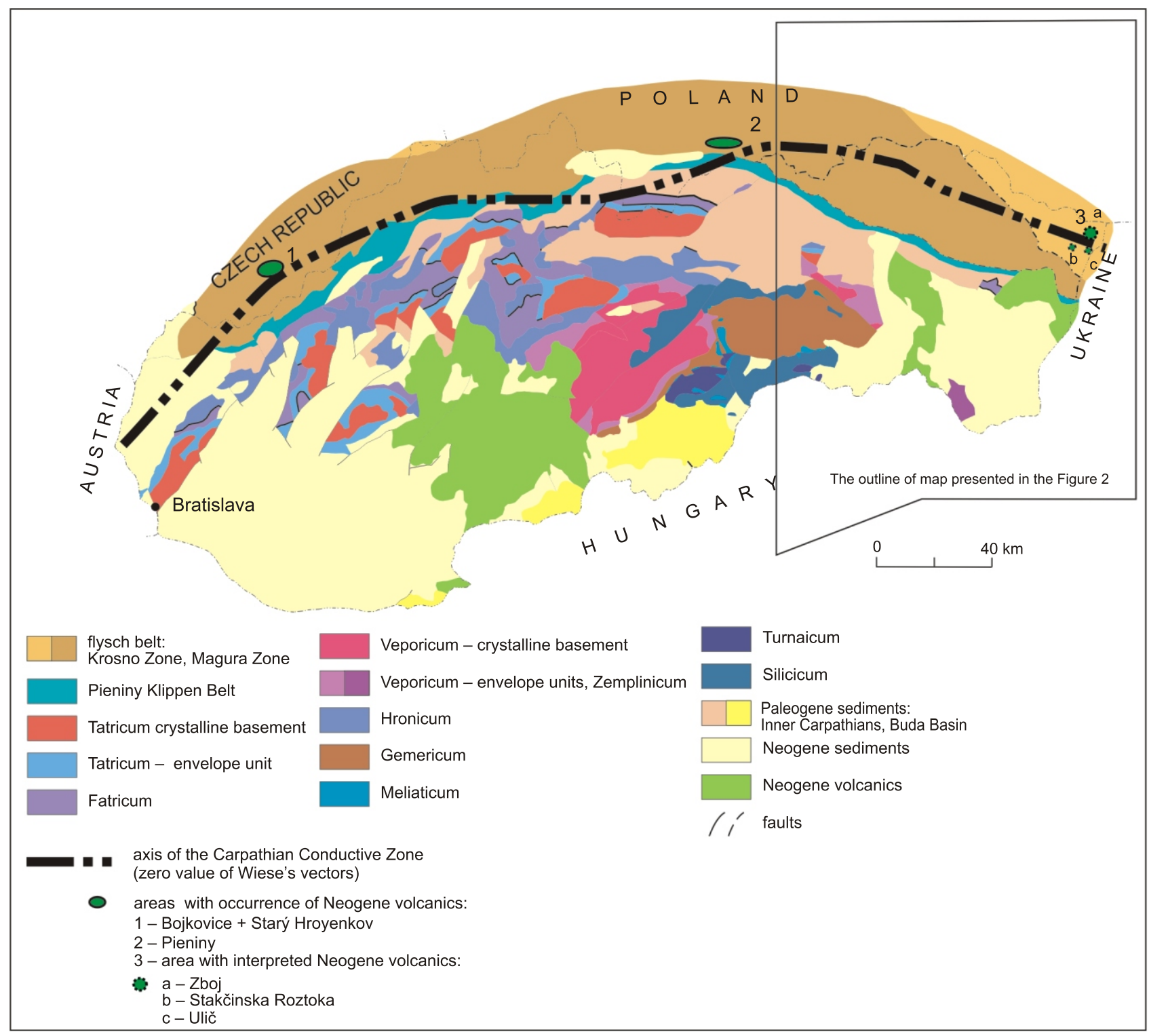

Fig. 1. Position of the Carpathian Conductivity Zone and occurrences of Neogene volcanic bodies and interpreted subvolcanic bodies in the Outer Carpathians (geological scheme based on Biely et al., 1996; Lexa et al., 2000)

The results show, that a rock body, which is not a stratigraphic member of the flysch sequence, may be the source of the magnetic anomaly. This rock body is more consistent with a discordant hypabyssal volcanic body. In this paper we provide a model of the geological body that might be related to this unusual magnetic anomaly, and highlight the implications of this model for better understanding of the evolution of the Outer Carpathian realm.

\section{GEOLOGICAL SETTING}

The principal tectonic division of the Western Carpathians into Outer and Inner ones (e.g., Bezák et al., 2004) is based on effects of the last important tectonic activity during the Neogene. A substantial volume of the crust in the Inner Western Carpathians is formed by Hercynian crystalline complexes, which are components of Palaeoalpine tectonic units: Tatricum, Veporicum, Gemericum (e.g., Bielik et al., 2004). The configu- ration of Palaeoalpine structure of the Inner Carpathians is supplemented by superficial nappes, composed mostly of Mesozoic, perhaps even of Upper Paleozoic, rock sequences (e.g., Plašienka et al., 1997).

The Paleogene and Neogene sedimentary infill of basins superimposed on the Alpine thrust-fold belts (Tari and Horváth, 2006) and the Neogene volcanic rocks in the Inner Carpathians represent successions formed after emplacement of the Inner Carpathian Palaeoalpine nappes. Basin formation as well as the volcanic activity was connected with the youngest tectonic development of the Inner Western Carpathians (asthenolite ascent, thinning of crust, activation of faults and increasing heat flow). The development of Neogene volcanism in time and space has been widely described (e.g., Csontos et al., 1992; Lexa and Konečný, 1998; Konečný et al., 2002; Pécskay et al., 2009).

The Outer Carpathians are composed of a stack of nappe sheets extending along the Carpathian arc, which may be up to six kilometres thick. There are several opinions as to the dis- 


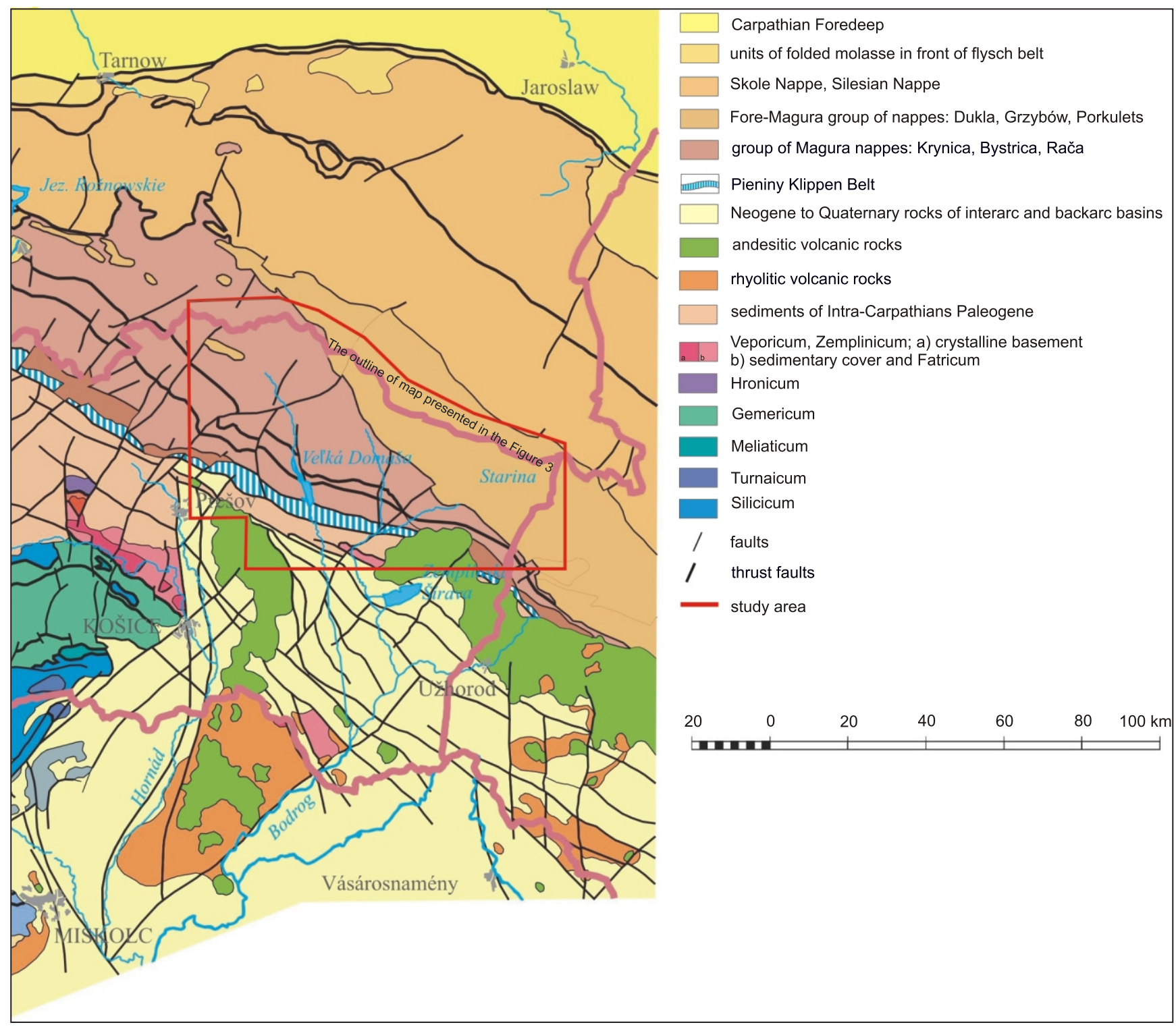

Fig. 2. Geological map of the eastern part of Slovakia (based on Lexa et al., 2000)

tance of thrusting of the Outer Carpathians nappes over the southern part of the North European Plate (e.g., over $70 \mathrm{~km}$, Golonka et al., 2005). The latest paper analysing these problems is Gagała et al. (2012). These nappes became detached from the basement during overthrusting. Behrmann et al. (2000) concluded about $260 \mathrm{~km}$ shortening in the NE Outer Carpathians. The nappe succession from highest to lowest ones comprises Magura Nappe, Fore-Magura group of nappes, Silesian Nappe, Subsilesian Nappe, and Skole Nappe.

The Outer Carpathian nappes are cut by several major faults of different origin. The last tectonic phase that affected the Outer Carpathians took place in the Miocene. The tectonic mobility in this period occurred during collision between the overriding ALCAPA Block and the North European Plate (Cieszkowski, 2003).

There are two nappes of the Outer Carpathians Flysch Belt developed in NE Slovakia: the Magura Nappe and the Dukla Nappe. The Magura Nappe system is the largest tectonic unit of the Western Carpathians and consists of several nappes (from the south to the north): the Krynica Nappe, the Bystrica Nappe and the Rača Nappe (Ślączka et al., 2006).

The Dukla Nappe emerges from beneath the Fore-Magura nappes (Ślączka, 1970). Boreholes (Smilno-1 and Zboj-1) show, that these nappes extend beneath the Magura Nappe far to the south (Durkovič et al., 1982; Leško et al., 1987). The area of our investigation is entirely located within the Dukla Nappe that contains in this area the Sub-Menilite, Cisna and Łupków beds.

\section{RESULTS OF PREVIOUS WORK}

A generalized geological map of the study area, based on Lexa et al. (2000), is shown on the Figure 2.

More detail appears on the 1:50 000 geological map of this part of the flysch belt in (Koráb, 1983). The map covers a more extensive region than that of the anomaly and contains no records of about occurrences of magnetic minerals or rocks. In 


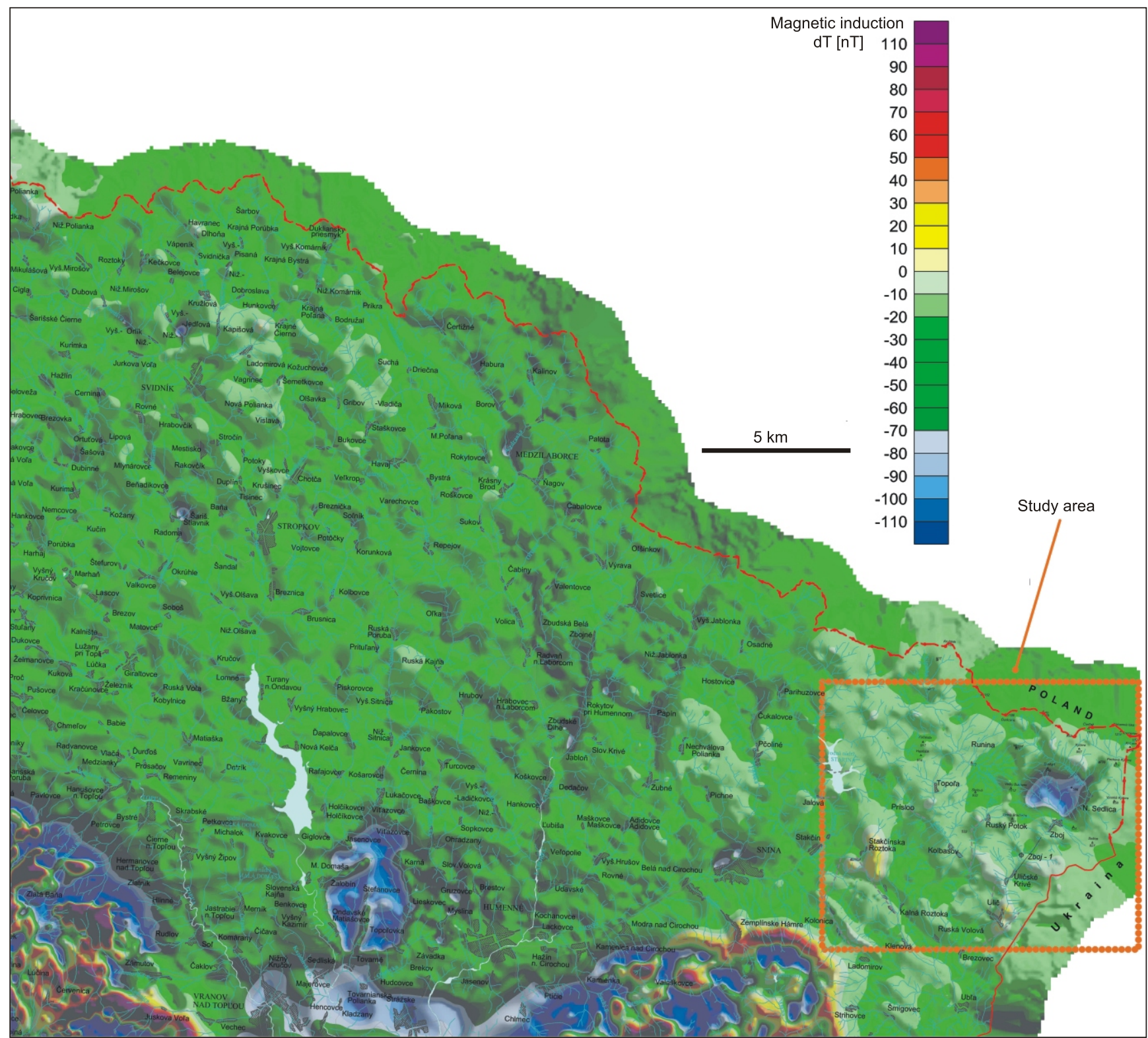

Fig. 3. Magnetic map of the NE part of Slovakia (according to Kubeš et al., 2008)

the geological cross-section of this area (Koráb, 1983) the Sub-Menilite Beds and Cisna Beds create a synclinal structure on the Łupków Beds (cf. Fig. 5). At this locality, that regional strike of beds (NW-SE) is in this part of the flysch belt changes almost into a $\mathrm{N}-\mathrm{S}$ direction.

Further knowledge has been gained from the deep borehole Zboj-1, drilled not far from this anomaly (Ďurkovič et al., 1982), at a time when the magnetic anomaly was unknown. The borehole was sited approximately $6 \mathrm{~km} \mathrm{SW}$ of the anomaly in the Zboj Spring Valley (see Fig. 4) within the Dukla Unit. Data from this borehole, of final depth $5002 \mathrm{~m}$, were used in magnetic anomaly interpretation. The borehole penetrated the following units (Table 1).

The upper $3800 \mathrm{~m}$ were within the Dukla Unit. The Zboj Beds found below this level compare with the Obidowa-Slopnice Unit (Ďurkovič et al., 1982), but these beds might also represent the innermost part of the Silesian Unit (Ślączka et al., 2006).

The borehole was evaluated not only as regards lithology and structure but also in terms of hydrogeology and hydrocar- bon occurrences. Notably, there is a potential for hydrocarbons (methane; Rudinec, 1989). Results of drill core logging and temperature measurements, were later included into the Atlas of Geothermal Energy of Slovakia (Franko et al., 1995).

This part of the Outer Carpathian Flysch Belt has lately been investigated regarding hydrocarbon potential (Hrušecký et al., 2003), using a variety of methods. Vitrinite reflectance, fission track and fluid inclusion data from near the Zboj-1 borehole as well as from the borehole core have shown that this area was affected by increasing temperature during the Neogene.

The first magnetic measurements in this area derive from synoptic airborne mapping of former Czechoslovakia 1:200 000 at scale, magnetic and radiometric measurements, $2 \mathrm{~km}$ flightline spacing. The results comprise 1:200 000 aeromagnetic maps (Mašín, 1963). The magnetic measurements were carried out with low accuracy $( \pm 25 \mathrm{nT})$ and therefore interpretation of the magnetic field within areas of narrow variation in amplitude is problematic. 
The simplified geological profile of the borehole Zboj-1 (modified after Durkovič et al., 1982)

\begin{tabular}{|c|c|}
\hline Depth [m] & The rock complex \\
\hline $0-300$ & $\begin{array}{c}\text { SUB-MENILITE BEDS - sandy gray and green-gray non-calcareous or weak calcareous claystones alternating with } \\
\text { mica silts (age: Paleocene) }\end{array}$ \\
\hline 300-800 & $\begin{array}{l}\text { CISNA BEDS - developed as typical flysch sequence; the share of sandstones is from } 30-80 \% \text {, beds are only slightly } \\
\text { tectonically deformed (age: Paleocene). }\end{array}$ \\
\hline $800-3800$ & $\begin{array}{l}\text { ŁUPKÓW BEDS - claystones-sandy flysch; the ratio claystones: sandstones is } 4: 1 \text {; the colour of claystones is dark } \\
\text { grey; calcareous share in sandstones is very variable 1.4-35.7\% (age: Cretaceous-Paleogene) }\end{array}$ \\
\hline $3800-5002$ & $\begin{array}{c}\text { ZBOJ BEDS - main lithotype the massive sandstones with homogeneous texture (the content of } \mathrm{SiO}_{2} \text { is } 53-89 \% \text { ); the } \\
\text { top of beds is tectonic decomposed (age: Upper Eocene to Lower Oligocene?) }\end{array}$ \\
\hline
\end{tabular}

The eastern part of the flysch belt in Slovakia has been subject of hydrocarbon prospecting in the second half of 20th century, mostly using seismic refraction and reflection surveying. Evaluations of seismic investigation within this area are given by Mořkovský et al. (1992) and Gągała et al. (2012). However, these profiles are not reliable for interpretation, because they ended in the area and therefore are affected by technical problems in signal processing. Magnetotelluric measurements are situated outside of this locality (Ryłko and Tomaś, 1995; Stefaniuk, 2006). However, for decades this area has been known to possess important regional (Carpathian) geophysical anomalies: an axis anomaly of the Carpathian Conductivity Zone-CCZ (e.g., Berdichevski and Dmitriev, 1976; Červ et al., 1984) and the southern edge of the Carpathian Gravity Low Zone (Tomek et al., 1979; Bielik, 1998). The situation of the lo- cality with the magnetic anomalies and with these regional anomalies is shown in Figure 4.

The magnetic anomaly source map of the Carpathian-Pannonian region distinguishes the following magnetic sources (Pospíšil and Ádám, 2006): (a) sources of platform origin, (b) Neogene volcanic rocks, (c) Alpine and Neogene sources. Each of these sources is characterized by a typical configuration of magnetic field. The outcrop of the Magura and Dukla nappes on the magnetic map show anomalies characteristic of platform and Alpine Paleogene sources that occur outside of Slovakia. This is represented by an extensive magnetic anomaly detected south of Dukla village (Poland) where the Rača, Dukla and Silesian nappes are present at the surface (Woźnicki and Šucha in Poprawa and Nemčok, 1988-1989).

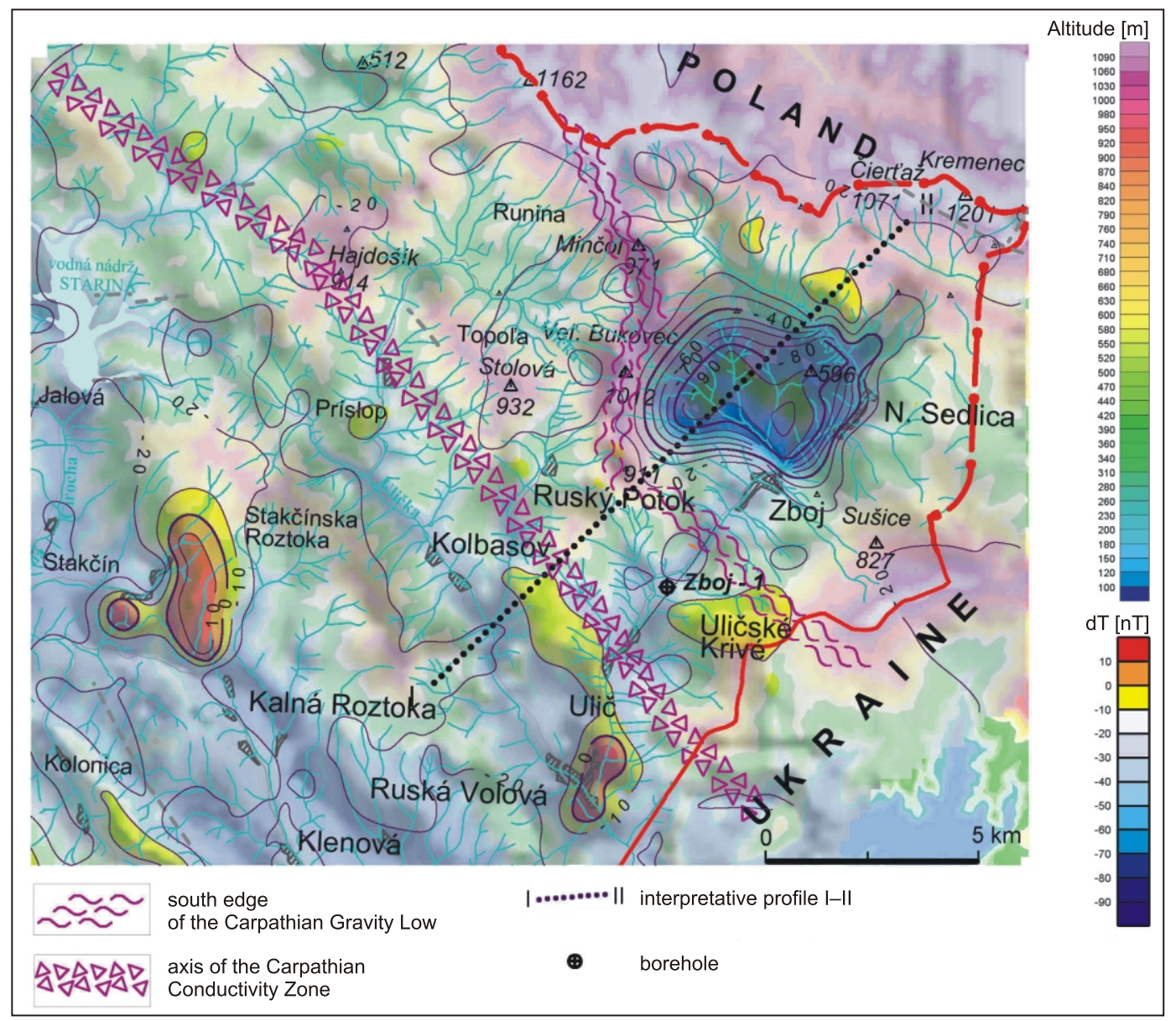

Fig. 4. The magnetic anomalies of the area studied and the Carpathian geophysical anomalies 
New additional magnetic measurements have been carried out in the last years (Kubeš et al., 2008), by ground application of proton magnetometry with a density of 1-3 points $/ \mathrm{km}^{2}$ (Kubeš et al., 2008). The accuracy of these measurements enables compilation of a magnetic map with isolines at $10 \mathrm{nT}$ intervals. The density of the measurements is sufficient for a construction of a map at the scale of 1:50 000. All measurements were reduced to the normal magnetic field (IGRF 1995 - International Geomagnetic Reference Field). Thus, a comprehensive database of magnetic anomalies $\Delta \mathrm{T}$ has been produced, which is the basis for the new magnetic map of the Slovak Republic. Geological interpretation of this magnetic map is given in Kubeš et al. (2010).

\section{GEOPHYSICAL 2D MODELLING}

The anomaly under discussion on the magnetic map of Slovakia (Kubeš et al., 2010) is characterized by negative amplitude, which reaches a value almost 100 nT (see Figs. 3 and 4). The anomaly possesses an approximately concentric shape and relatively steep magnetic gradient. No signs of magnetic rocks have been recorded at the surface in that area, which topographically comprises a depression (see Fig. 4).

The negative magnetic anomaly was modelled using OASIS MONTAJ software in 2D space. We have used only the magnetic part of this code, because gravity modelling in such an area offers many interpretations. Gravity maps for different volume densities and with different filters have been processed from the gravity field but without conclusive results. The magnetic modelling though is more objective, due to the narrower scale of inherence of magnetic rocks. Because specific magnetic data of the inferred anomaly - producing body was not available, we used indirect information from previous work. Evidence of a thermal event dated to Neogene (Hrušecký et al., 2003) suggest the source of this anomaly may be magmatic. The shape of this anomalous field excludes to consider presence of a magnetic object of sedimentary origin, while the gradient of the anomaly excludes the presence of magnetic rock on the surface. A typical feature of Neogene volcanic rocks in Slovakia is multiple alternation of magnetic field polarity and many rocks bodies (mostly andesites) are expressed in a magnetic field by negative anomalies (Filo et al., 2003). Thermal remanent magnetic polarisation, which is characteristic of igneous rocks, can produce a reversed magnetic field - hence we utilized remanent magnetization when modelling. Modelling was undertaken despite good coincidence between the observed and calculated curves after a technical interpretation (Fig. 5). It was important to clarify the origin of the magnetic anomaly and to integrate the interpreted geological cause of the anomaly into its lithological and structural context in the area. In the terms of our previous interpretation (Kubeš et al., 2010) we were able to assign almost all magnetic anomalies from the Western Carpathian area to an appropriate geological unit. The pattern of the magnetic anomaly and surrounding magnetic field indicates that the body responsible for the anomaly did not reach ground the surface. In plan the anomaly is almost circular. Missing positive values of the magnetic field indicated, suggest that rocks with remanent magnetic polarization created that anomaly. In the Western Carpathians area (Kubeš et al., 2010), such magnetization is typical of younger Cenozoic magmatic rocks (flysch rocks also possess remanent magnetization but usually of very low intensity). Hence the final geophysical model took the form of a tube of diameter around $2 \mathrm{~km}$, dipping to the NE. Our interpretation contains ambiguities regarding the depth, thickness and precise magnetic properties of the disturbing body. It is clear, though, that the shape and the inclination of anomalous body is discordant to the flysch strata (assuming a magnetic susceptibility of around $1000 \times 10^{-6}$ [cgs units]). The anomalous body therefore may represent a subvolcanic neck of intermediary composition of Miocene age, with influence of thermoviscous polarity. A geological cross-section adopted from older data (Koráb, 1983) using the results of 2D magnetic modelling is shown in Figure 5.

Two other anomalies have been recognized in this area. Both are situated to the SW of the main one on the opposite side of the CCZ (see Fig. 4) near the villages of Stakčínska Roztoka and Ulič. They show similar features: small relative positive amplitudes of magnetic field (20-30 nT) and linear shapes located in valleys. The 2D shapes of the anomalies, suggest thin dykes of intermediate composition. The top of the bodies lie closer to the surface and we infer that the valleys were established along fault zones that facilitated magma ascent towards the surface.

\section{GEOLOGICAL INTERPRETATION}

The principal outputs of 2D magnetic modelling for geological interpretation are as follows:

- the anomaly is caused by a cylindrical body with a width of almost $2 \mathrm{~km}$ inclined to the north-east;

- the roof of the anomalous body is situated at a depth of about $1 \mathrm{~km}$ and its surface is almost subhorizontal;

- modelling used remanent magnetic polarization.

The anomalous body may represent a subvolcanic neck (Fig. 5).

The presence of a possible subvolcanic body is supported by :

- Small Neogene hypabyssal calc-alkaline andesitic dykes and sills have been observed between Szczawnica and Czorsztyn in the Pieniny area of Poland along and less than $4 \mathrm{~km}$ from (Birkenmajer et al., 2004). The andesite bodies are located in the Outer Flysch in the Magura Unit and Birkenmajer et al. (2004), Trua et al. (2006) inferred a large magmatic chamber at depths of about $10-15 \mathrm{~km}$, associating them with subduction. Hydrothermal alteration and ore mineralization have been observed inside the andesite bodies as well as in the adjacent areas. The radiometric age range of these rocks has been determined as 10.8-13.3 Ma (Pécskay et al., 2006).

- Similarly a cluster of shoshonitic basalts and andesites is developed in the form of small irregular bodies within the Beloveža Beds in the western part of the flysch belt around Bojkovice township and Bánov (Bielokarpatská Unit) in the Czech Republic (see Fig.1). Krejčí and Poul (2010) gave the newest data from this area. Intensive altered rocks were emplaced along the faults active in the Middle Miocene. The bodies are $10-15 \mathrm{~km}$ from the Klippen Belt. Their radiometric age range has been determined as 11.0-13.5 Ma (Pécskay et al., 2006), the same age as the volcanic rocks in the Pieniny area.

- At both localities volcanic rocks are developed along the axis of the Carpathian Conductivity Zone (CCZ) - the zone of zero value of Wiese's vector (Fig. 1).

- The locality studied here lies in a similar position. The CCZ is situated very close to the southern margin of the magnetic anomaly. The distance of the anomaly from the PKB is around $25-30 \mathrm{~km}$. This means that the CCZ 

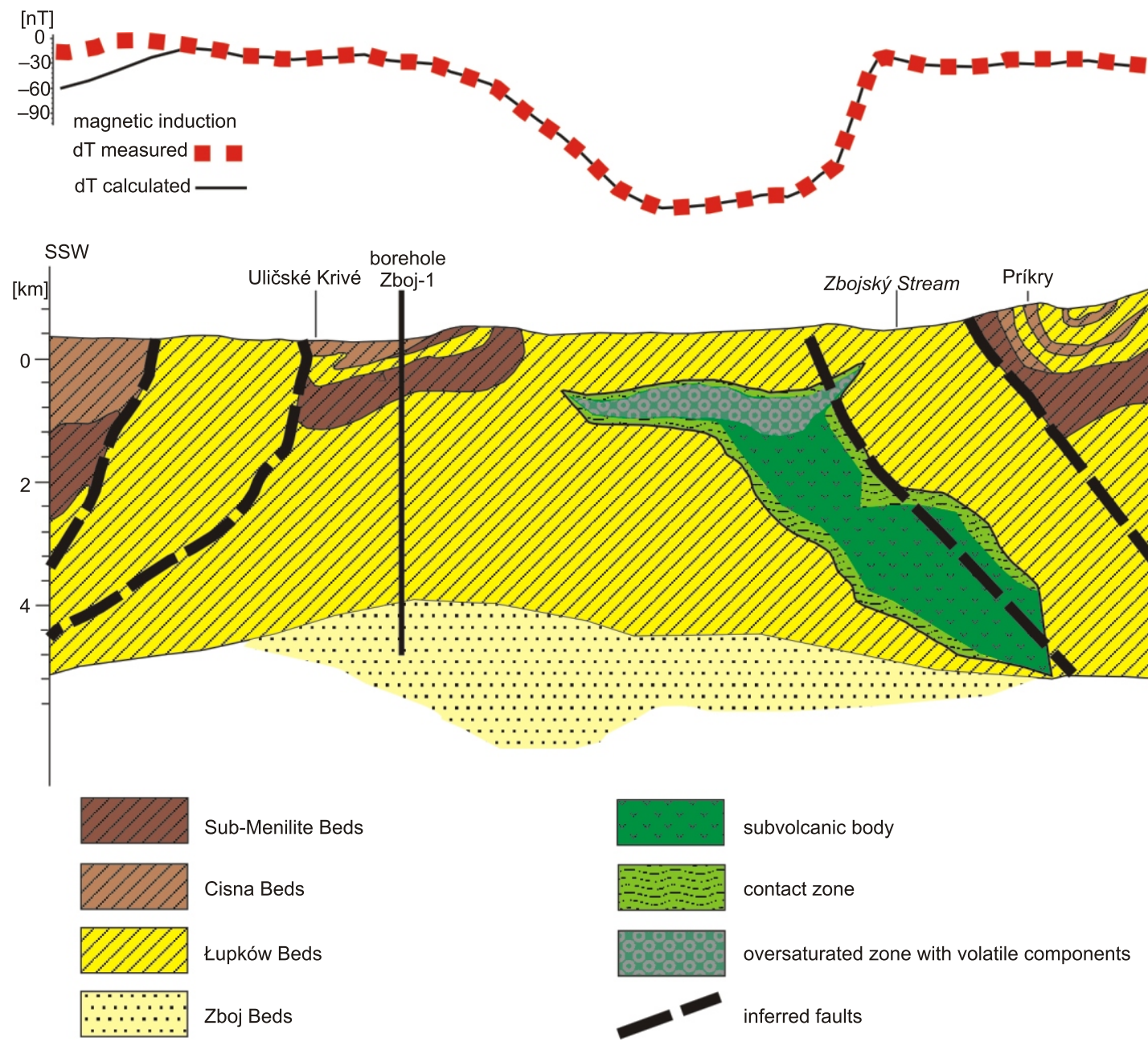

Fig. 5. 2D magnetic modelling and geological interpretation of magnetic data

is a controlling feature for volcanic bodies situated north of the Klippen Belt. This observation suggests that the relation of the CCZ and the PKB may be reconsidered.

Other features support interpretation of subvolcanic bodies:

- The Atlas of geothermal energy of Slovakia (Franko et al., 1995) shows this area a temperature at the depth of $1000 \mathrm{~m}$ on the level of $50^{\circ} \mathrm{C}$. This value is similar to those in substantial parts of the Danube Basin and the East Slovakia Basin (results from the Zboj-1 borehole; Durkovič et al., 1982). Our interpretation indicates that the upper edge of magnetic body lies approximately at that level. The lower levels of the borehole Zboj-1 do not show anomalous values of temperature, consistent with our interpretation of an anomalous body dipping to the NE (see Fig. 5).

- Rock samples collected from the surface near the Zboj-1 borehole (Hrušecký et al., 2003) and from the core borehole show vitrinite reflectance $\left(R_{r}\right)$ values that are the highest in the Dukla Unit in Slovakia. Normal values are between $0.48-0.59 \%$, while reflectance values at the surface close to the Zboj-1 borehole are $1.23-1.49 \%$, and in the Zboj-1 borehole at a depth of $1105 \mathrm{~m}$ they are $1.62-1.67 \%$. These results indicate that these rocks were metamorphosed to almost $200^{\circ} \mathrm{C}$.
The vitrinite reflectance values suggest an age interval of 10-20 Ma for this (Kotulová in Hrušecký et al., 2003). These temperature changes did not take place during basin formation or during tectonic activity (ibid).

- Fission track dating on detrital apatites has also been carried out in that area giving results suggesting ages within the Sarmatian or the Sarmatian-Middle Pannonian, the age range of 9.9-17.2 Ma (Hrušecký et al., 2003) see Table 2.

- Thermometric analysis of the fluid inclusions has been carried out on the surface samples near the Zboj-1 borehole. The results obtained suggest that fluids within joints were composed of various proportions of water, crude oil, gasoline, methane and carbon dioxide with temperatures of $130-220^{\circ} \mathrm{C}$. This value is consistent with those from vitrinite reflectance of $128-178^{\circ} \mathrm{C}$. The pressure of fluids assessed on the base of micrometric study fluctuated from 1093 to 3694 bars. This pressure considerably exceeds the lithostatic pressure which resulted in joint formation (Hrušecký et al., 2003). Comparing the planar shape of the anomaly and the relief of the terrain (see Fig. 4) suggests that the ridge of the Bukovské vrchy Mts. (Paleogene), lying almost $\mathrm{N}-\mathrm{S}$, has been "pushed" to the west at the margin of the 
Table 2

Dispersion of fission track dating in sediments (apatite) the geological units of the east Slovakia (after Hrušecký et al., 2003)

\begin{tabular}{|l|c|c|c|}
\hline \multicolumn{1}{|c|}{ Geological unit } & $\begin{array}{c}\text { Number of } \\
\text { samples }\end{array}$ & $\begin{array}{c}\text { Min.age } \\
{[\mathrm{Ma}]}\end{array}$ & $\begin{array}{c}\text { Max.age } \\
{[\mathrm{Ma}]}\end{array}$ \\
\hline $\begin{array}{l}\text { Transcarpathian } \\
\text { Depression }\end{array}$ & 4 & 13.9 & 24.8 \\
\hline $\begin{array}{l}\text { Inner Carpathian } \\
\text { Paleogene }\end{array}$ & 18 & 23.3 & 36.9 \\
\hline Klippen Belt & 1 & 12.3 & - \\
\hline Krynica Unit & 16 & 12.0 & 28.7 \\
\hline Rača Unit & 16 & 14.5 & 25.0 \\
\hline Dukla Unit & 9 & 9.9 & 17.2 \\
\hline
\end{tabular}

anomaly as a consequence of the Neogene intrusion. The ridge of the Bukovské vrchy Mts. is created by rigid sandstones of the Cisna Beds, while the inferred intrusion stopped its ascent in the soft clay sequence of the Łupków Beds. A combination these lithological features and tectonic and exogenous processes shaped the relief of the field into the form seen today.

- These factors combined with modelling of the magnetic anomaly, suggests that the probable source of the magnetic anomaly is a subvolcanic body of diorite porphyry which intruded into this area during the Sarmatian. Placing the inferred body into the context of young Carpathians volcanic rocks, following Pécskay et al. (2006), this anomaly might be related to mafic to calc-alkaline rocks (intrusions), age of range between 10-14 Ma, similarly to the volcanic rocks observed in eastern Moravia, the Pieniny Mts., the Slánske vrchy Mts., the Vihorlat Mts. and the Gutin Range in Ukraine.

\section{DISCUSSION}

The PKB basin closed at the Cretaceous/Paleogene transition as an effect of strong Late Cretaceous (Subhercynian and Laramian) thrust folding. The last important events in the PKB were the Neogene transpression and Sarmatian volcanism represented by andesite dykes and sills, which cut mainly Paleogene flysch (Magura Nappe) and formed the so-called Pieniny Andesitic Line (Krobicki et al., 2003). We may conclude that Sarmathian volcanism cut the Dukla Nappe as well.

However, Jurassic and Cretaceous volcanic rocks are also present within the Outer Carpathians of Transcarpathian Ukraine and in the Silesian or Subsilesian nappes within the Polish-Czech border region and in egocina SW from Kraków (Golonka, 2004; Krobicki et al., 2004). Such volcanic rocks, though, are unlikely to lie within the area under study. The roof of the interpreted anomaly is at the depth of approximately $1000 \mathrm{~m}$ and even if we will consider the Zboj Beds (from the Zboj-1 borehole) as a part of the Silesian Nappe, their depth $(3800 \mathrm{~m})$ is too great to cause the magnetic anomaly recognized. Furthermore, an existence of volcanic rocks older than Miocene (Jurassic and Cretaceous) could not have directly influenced of the Paleogene environment.

Although the occurrence of intrusive rocks in front of the PKB are rare, our investigation suggests that such objects may exist in the subsurface. Birkenmajer et al. (2004) interpered this event as a component of melange of the Outer Carpathians. The Pieniny Mts. andesites, which occur at or near to the Outer/Inner Carpathian tectonic junction, find their equivalents in the west in the Moravian Carpathians and, in the east, in Transcarpathian Ukraine, the Vihorlat Mts., Gutai (Baia Mare region, NW Romania), and as a subvolcanic unit at Toroiaga, Radna and Borgon (NW Romania). The andesite intrusions at these locations belong to the outermost (northernmost) post-collisional late Middle Miocene (Sarmatian) volcanic arc of the West Carpathian orogeny that is some $400 \mathrm{~km}$ long - the Pieniny Volcanic Arc (Birkenmajer et al., 2004).

Major and trace elements chemistry of the intrusive rocks indicate subduction-related magma sources, as in volcanic rocks of the Carpathians. The three intrusive phases distinguished within the interval have been dated as $14.76 \pm 1.18 \mathrm{Ma}$ to $11.04 \pm 1.21 \mathrm{Ma}$ (with eastwards age migration along the Carpathian arc; Pécskay et al., 2006).

Intrusive activity continued in Romania to $11.5-8.0 \mathrm{Ma}$ (Pécskay et al., 2009), clearly indicating migration of the subduction zone from west to east. This is a similar trend of migration of the intrusive activity as in volcanic activity in the main volcanic chain.

The intrusive rocks are generally affected by postmagmatic alteration. The boron geochemistry of the andesite intrusions is typical of subduction related calc-alkaline rocks. Subduction fluids under the Moravian and the Toroiaga regions (Romania) probably originated from the crust, while in the Pieniny they derived from subducted flysch deposits (Gmélin et al., 2007). However, according to Jurewicz and Nejbert (2005) the geotectonic position of the Pieniny andesites suggests connectivity with deep crust faults rather than with processes of subduction.

Regarding the oblique course of Neoalpine collision and the gradual migration of the subduction zone along the Carpathian arc to the east and to the south-east it is highly probable, that individual volcanic centres formed in different geotectonic environments (Lexa and Konečný, 1998). These authors have classified the Western Carpathians volcanics into two groups: the first one linked to a subduction zone (east Slovakia) and the second is related at the asthenolite ascent and extension processes (central Slovakia). The provenance of volcanic bodies at the tail of the subduction zone is possible to explain either with continuing extension after regression/migration of the subduction zone to the south-east, or via faults systems that originated earlier above the subduction zone. This latter seems to more feasible because the subduction zone than was elsewhere with a different orientation.

Besides the main magnetic anomaly in question, small positive anomalies to the south suggest that the presence of igneous rocks behind the PKB locally (e.g., the Morské Oko volcano in the Vihorlat Mts.) is in a similar setting.

\section{THE RELATIONSHIP BETWEEN CARPATHIAN CONDUCTIVITY ZONE AND THE PIENINY KLIPPEN BELT AND MAGNETIC ANOMALIES}

Several factors need to be taken into consideration in interpretating the Neogene volcanic bodies that lie within the zone of the PKB and behind this zone in the flysch belt. The $\mathrm{PKB}$ is mostly regarded as representing the surface of the Eu- 


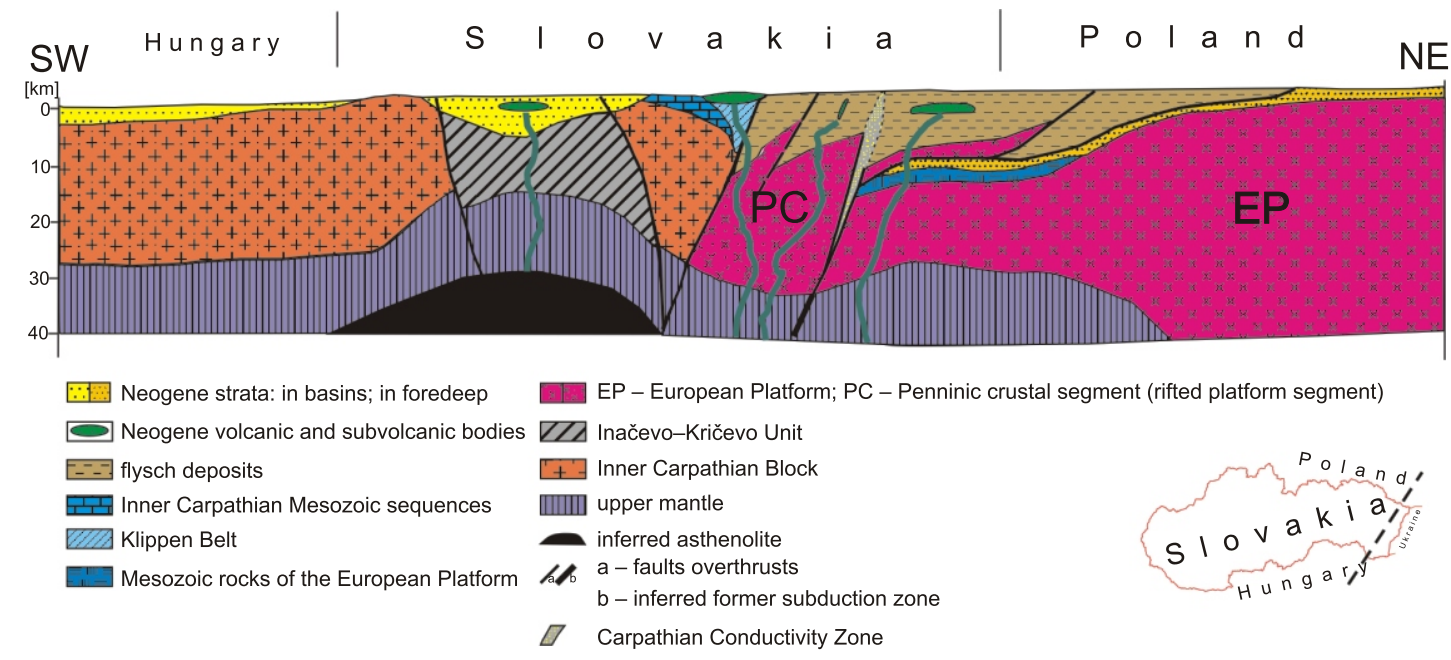

Fig. 6. Schematic cross-section of the crust in the eastern part of Slovakia (adapted from Bezák et al., 1997)

ropean Platform margin, and hence the boundary of subduction during Neoalpine orogenesis (e.g., Oszczypko et al., 2002).

The position of known and interpreted volcanic rocks in relation to the CCZ is depicted in Figure 6. However, the depth of CCZ is greater than the depth of the igneous bodies. In our interpretation this zone represents a deep-seated fault system, along which magma intruded into the flysch deposits.

The course of the CCZ has been using magnetotelluric measurements along the whole Carpathian arch from the $\mathrm{Vi}$ enna Basin to Romania (Berdichevski and Dmitriev, 1976; Červ et al., 1984; Stanica et al., 1999; Ádám, 2001; Hvožd'ara and Vozár, 2004). Most of these authors agree that this is a deep-seated fault zone, which enabled flux of heat and often of mineralized fluids from the mantle. These fluids were enriched in $\mathrm{CO}_{2}$ and $\mathrm{CO}$, reduction of which produced carbon films in the rock. This zone is detected at depths of $5-25 \mathrm{~km}$, as part of the crust comprising crystalline blocks. Its manifestation in the conductive sedimentary unit of the flysch rocks is practically negligible (Hvožd'ara and Vozár, 2004). The origin of such a remarkable large-scale structure is possible to explain by the movement of large tectonic blocks only. We consider this took place by oblique movement of the Inner Carpathian Block and the European Platform, or of its rifted blocks.

The spatial position of the CCZ is independent of the PKB (see Fig. 1). In the central part of Slovakia, the CCZ is displaced to the south and in the eastern and western part of Slovakia it is located to the north of the PKB. This may indicate interference of platform segments below the Inner Western Carpathians. This possibility is consistent with isostatic rising of the Tatra Mts. and Malá Fatra Mts. (Maglay et al., 1999). It suggests that the real margin of the European Platform (EP) is the CCZ, and the PKB seems to be a shallow structure detached from the Inner Western Carpathians.

As regards regional tectonics, there are several significant points. The interpretation of the geological cross-section through the east Slovakia (Fig. 6) suggests on the basis of geophysical data, that the platform, before collision comprised another block and that the PKB is not the real margin of the platform. The CCZ may have been created by horizontal displacement at the contact between the Inner Western Carpathians blocks and blocks derived of European Platform and the platform itself.
This interpretation is supported by seismic models of the CEL-11 profile (Janik et al., 2011), part of the CELEBRATION 2000 project, where the European Platform margin is situated north of the Klippen Belt and where, in the space between the European Platform and the Klippen Belt, a newly interpreted Pieniny crustal segment has been inserted.

\section{SIGNIFICANCE OF THE PROPOSED INTERPRETATION TO APPLIED GEOLOGY}

Aside from discussion of the genesis of this possible Neogene igneous body, there are several implications for applied geology in particular as regards metalogenesis, possibilities for $\mathrm{CO}_{2}$ storage and hydrocarbon potential.

Andesite dykes in the Pieniny Mts. (Poland) cause the contact metamorphism in neighbouring rocks. The final products may include at small deposits of gold, silver and lead. These ores had been briefly exploited at the beginning of the 18th century (Szeliga and Michalik, 2003; Birkenmajer et al., 2004). A correlation between intrusion emplacement and mineralization has being demonstrated (Birkenmajer et al., 2004).

Similarly, igneous rocks in the Czech Republic (Middle Miocene) are intensively altered (propylitisation) and contact metamorphism has been observed in the neighbouring flysch deposits (Krejčí and Poul, 2010).

There are further occurrences of mineralization in Romania, where ore deposits are associated with intrusives representing $\mathrm{Sb}-\mathrm{As}-\mathrm{Ag}-\mathrm{Zn}-\mathrm{Pb}-\mathrm{As}-\mathrm{Cu}$ vein mineralization and disseminated copper - enriched ore (Cu-Zn-Pb,) in the Tibles area and argillic hydrothermal alteration associated with $\mathrm{Cu}-\mathrm{Pb}(\mathrm{Au})$ mineralization in the Rodna-Bargau area (Pécskay et al., 2006).

Hence a similar type of mineralization might be expected in the exo- and endo-contact of the intrusive body interpreted.

Consideration of underground storage of $\mathrm{CO}_{2}$ has parallels with hydrocarbon geology. Volcanoes emit large amounts of volcanic gas exsolving from the erupting magma during explosive and effusive eruption and non-eruptive continuous degassing. Degassing of large volume of non-erupted magma can cause considerable degassing; the erupted magma represents 
only a small portion of the magma that drives volcanic activity (Shinohara, 2008).

We may expect a large volume of rocks to have been affected by degassing of magma, because the intrusion has lost kinetic energy at the lithological boundary within the Łupków Beds, the magma than cooling and crystallizing. Volatile bubbles, ascending through buoyancy, will have accumulated in the upper part of the intrusive body. Crystallization of magmas concentrates volatile components in the melt, causing volatile saturation - bubble formation (Shinohara, 2008). As the body remains unerupted, is reasonable to suppose that the volume of rocks including volatile components may be remarkable (see Fig. 5).

Permeable magma foam can form to allow gas escape once bubbles become interconnected. Magma permeability can be much higher than wall-rock permeability, and so vertical gas loss can be an important escape path, in addition to gas loss through the conduit walls (Sparks, 2003).

The local stress field and complex interactions of buoyancy forces, host rock resistance to fracture, elastic deformation of country rock, magma hydrostatic pressure and fluctuating magma pressure, magma viscosity and weight of overburden control the emplacement process (Planke et al., 2003). On a longer time scale, the dominant processes near intrusions include release of mineral-bound fluids, pore pressure increase and hydrofracturing. Hydrofracturing occurs when the rate of fluid production exceeds the rate of fluid migration (Svensen et al., 2004). Part of the secondary porosity observed in this area may result from this process.

We may refere inter reformation of permeable environments within the upper part of the igneous body, perhaps at the contacts.

Data from the Zboj-1 borehole suggests some potential for hydrocarbons, especially within the Zboj Beds (Rudinec, 1989). The inferred intrusion may enhance this.

\section{CONCLUSIONS}

New magnetic measurements reveal several small magnetic anomalies and one large one in the NE part of the Slovakian flysch belt. These objects are interpreted as subvolcanic bodies of Neogene age. Their position is similar to those of known igneous bodies within the flysch zone of Moravia and Poland. The position of these igneous rocks near the Carpathian Conductivity Zone, suggests an important shear zone at the boundary between the European Platform and blocks of the Inner Western Carpathians. Other fault systems, which likely encouraged ascent of magma, were connected with this zone, following migration of subduction further along the Carpathian arc to the Easter Carpathians.

Consequences of interpretation of these magnetic anomalies in the Carpathian Flysch Belt for applied geology include mineralization, $\mathrm{CO}_{2}$ storage, hydrocarbons, and the general importance of the CCZ. However, testing of our hypothesis requires further work. This might include further geophysical investigations in other parts of the Carpathian arc along the $\mathrm{CCZ}$ and the PKB to develop a better understanding of relation between the Carpathians and the European Platform.

Acknowledgements. This work was supported by project No. 1307 - Quantitative parameters of selected geological structure suitable for $\mathrm{CO}_{2}$ storage - Ministry of Environment of Slovakia, by the grant VEGA No. 2/ 0088/12 and by the Slovak Research and Development Agency under the contract No. APVV-0194/10 and 0724/11. The authors express their thanks to J. Grabowski, J. Golonka and P. Krzywiec for constructive criticism and helpful comments during the preparation of this manuscript and to T. Peryt for overall improvement of this paper.

\section{REFERENCES}

Ádám A. (2001) An attempt to map the depth of the electrical asthenosphere by deep magnetotelluric measurements in the Pannonian basin (Hungary). Acta Geologica Hungarica, 44: 197-192.

Behrmann J.H., Stiasny S., Milička J., Pereszlényi M. (2000) Quantitative reconstruction of orogenic convergence in the northern Carpathians. Tectonophysics, 319: 111-127.

Berdichevski M.N., Dmitriev V.I. (1976) Distorsion of magnetic and electrical fields by near-surface lateral inhomogenities. Acta Geodaetica, Geophysica et Montanistica Academiae Scientarium Hungaricae, 11: 447-483.

Bezák V., Šefara J., Bielik M., Kubeš P. (1997) Models of the Western Carpathians lithosphere. In: Geological Evolution of the Western Carpathians (eds. P. Grecula et al.): 25-34. Mineralia Slovaca-Monograph, Bratislava.

Bezák V., Broska I., Ivanička J., Reichwalder P., Vozár J., Polák M., Havrila M., Mello J., Biely A., Plašienka D., Potfaj M., Konečný V., Lexa J., Kaličiak M., Žec B., Vass D., Elečko M., Janočko J., Pereszlényi M., Marko M., Maglay J., Pristaš J. (2004) Tectonic map of the Slovak Republic 1:500 000. ŠGÚDŠ Bratislava.

Bezák V., Biely A., Elečko M., Konečný V., Mello J., Polák M., Potfaj M. (2011) A new synthesis of the geological structure of
Slovakia - the general geological map at 1:200 000 scale. Geological Quarterly, 55 (1): 1-8.

Bielik M. (1998) Analysis of the gravity field in the Western and Eastern part of Carpathian junction area: density modelling. Geologica Carpathica, 46: 75-83.

Bielik M., Šefara J., Kováč M., Bezák V., Plašienka D. (2004) The Western Carpathians - interaction of Hercynian and Alpine processes. Tectonophysics, 393: 63-86.

Biely A., Bezák V., Elečko M., Kaličiak M., Konečný V., Lexa J., Mello J., Nemčok J., Potfaj M., Rakús M., Vass D., Vozár J., Vozárová A. (1996) Geological map of Slovak Republic 1:500 000. GÚDŠ Bratislava.

Birkenmajer K., Lorenc W.M. (2008) Lower Cretaceous exotic intraplate basaltoid olistolith from Biała Woda, Pieniny Klippen Belt, Poland: geochemistry and provenance. Studia Geologica Polonica, 131: 237-246.

Birkenmajer K., Pécskay Z., Szeliga W. (2004) Age relationships between Miocene volcanism and hydrothermal activity at Mt Jarmuta, Pieniny Klippen Belt, West Carpathians, Poland. Studia Geologica Polonica, 123: 279-294.

Cieszkowski M. (2003) The Outer Carpathians thrustbelt. Publications of the Institute of Geophysics, Polish Academy of Sciences, Monographic, 28 (363): 107-110. 
Csontos L., Nagymarosy A., Horváth F., Kováč M. (1992) Tertiary evolution of the intra-Carpathian area: a model. Tectonophysics, 208: 221-241.

Červ V., Pek J., Praus O. (1984) Models of geophysical anomalies in Czechoslovakia. Journal of Geophysics, 55: 61-168.

Ďurkovič T., Koráb T., Rudinec R., Gašparíková V., Snopková P., K hler E., Zakovič M. (1982) Hlboký štruktúrny vrt Zboj-1. Regionálna Geológia Západných Karpát, 16: 1-76.

Filo M., Konečný V., Kubeš P., Šimon L., Dublan Š., Kaličiak M., Lexa J., Gluch A. (2003) Zdroje magnetických anomálií v neovulkanitoch Slovenska. Geologicke Práce - Správy, 107: 47-172.

Franko O., Remšík A., Fendek M., Fusán O., Král' M., Bodiš D., Drozd V., Vika K., eds. (1995) Atlas of geothermal energy of Slovakia. GÚDŠ Bratislava.

Gągała Ł., Vergés J., Saura E., Malata T., Ringenbach J.-C., Werner P., Krzywiec P. (2012) Architecture and orogenic evolution of the northeastern Outer Carpathians from cross-section balancing and forward modelling. Tectonophysics, 532-535: 223-241.

Gméling K., Németh K., Martin U., Eby N., Varga Z. (2007) Boron concentrations of volcanic fields in different geotectonic settings. Journal of Volcanology and Geothermal Research, 159 (1-3): 70-84.

Golonka J. (2004) Plate tectonic evolution of the southern margin of Eurasia in the Mesozoic and Cenozoic. Tectonophysics, 381 235-273.

Golonka J., Aleksandrowski P., Aubrecht R., Chowaniec J., Chrustek M., Cieszkowski M., Florek R., Gawęda A., Jarosiński M., Kępińska B., Krobicki M., Lefeld J., Lewandowski M., Marko F., Michalik M., Oszczypko N., Picha F., Potfaj M., Słaby E., Ślączka A., Stefaniuk M., Uchman A., elaźniewicz A. (2005) The Orava Deep Drilling Project and post-Palaeogene tectonics of the Northern Carpathians. Annales Societatis Geologorum Poloniae, 75 : 211-248.

Hrušecký I., Kotulová J., Baráth I., Kubeš P., Ďurkovič T., Fejdi V., Pereszlényi M., Nemčok M., Janočko J. (2003) Uhl'ovodíkový potenciál východoslovenského neogénu a pril'ahlých oblastí flyšového pásma. Manuscript. Geofond, ŠGÚDŠ Bratislava.

Hvožd'ara M., Vozár J. (2004) Laboratory and geophysical implications for explanation of the nature of the Carpathian Conductivity Anomaly. Acta Geophysica Polonica, 52: 497-508.

Janik T., Grad M., Guterch A., Vozár J., Bielik M., Vozárová A. Hegedüs E., Kovács C.A., Kovács I., Keller G.R., Celebration 2000 Working Group (2011) Crustal structure of the Western Carpathians and Pannonian Basin: seismic models from Celebration 2000 data and geological implications. Journal of Geodynamics, 52: 97-113.

Jurewicz E., Nejbert K. (2005) Geotectonic position of the so-called "Pieniny Mts. andesites". Mineralogical Society of Poland, Special Paper, 25: 179-183.

Konečný V., Kováč M., Lexa J., Šefara J. (2002) Neogene evolution of the Carpatho-Pannonian region: an interplay of subduction and back-arc diapiric uprise in the mantle. EGU Stephan Mueller Special Publication Series, 1: 105-123.

Koráb T. (1983) Geological map of the Nízke Beskydy Mts., scale 1:50 000 - Eastern part. GÚDŠ, Bratislava.

Krejčí O., Poul I. (2010) Evidence of Middle Miocene thrust tectonics in the Bílé Karpaty Unit (Carpathian Flysch Belt). Geologické Výzkumy Moravy a Slezska: 58-63.

Krobicki M., Golonka J., Aubrecht R. (2003) Pieniny Klippen Belt: general geology and geodynamic evolution. Publications of the Institute of Geophysics, Polish Academy of Sciences, Monographic, M-28 (363): 25-33.

Krobicki M., Golonka J., Lewandowski M., Michalik M., Oszczypko N., Popadyuk I., Słaby E. (2004) Volcanism of the Jurassic-Cretaceous triple-junction zone in the Eastern Carpathians. Geolines, 17: 60-61.
Kubeš P., Kucharič L'., Gluch A., Kohút M., Bezák V., Potfaj M. (2008) Magnetická mapa Slovenska. Final report Manuscript. Geofond, ŠGÚDŠ Bratislava.

Kubeš P., Bezák V., Kucharič L', Filo M., Vozár J., Konečný V., Kohút M., Gluch A. (2010) Magnetic field of the Western Carpathians (Slovakia): reflection structure of the crust. Geologica Carpathica, 61: 437-447.

Leško B., Ďurkovič T., Faber P., Filkova V., Hradil F., Janku J., Losík K., Píchová E., Rudinec R., Samuel O., Smetana J., Snopková P., Wunder D. (1987) Oporný vrt Smilno 1 (5 700 m). Regionálna Geológia Západných Karpát, 22: 1-133.

Lexa J., Konečný V. (1998) Geodynamic aspects of the Neogene to Quaternary volcanism. In: Geodynamic Development of the Western Carpathians (ed. M. Rakús): 219-240. Geological Survey of the Slovak Republic.

Lexa J., Bezák V., Elečko M., Mello J., Polák M., Potfaj M., Vozár J., eds. (2000) Geological map of the Western Carpathians and adjacent areas: scale 1:500 000. Geological Survey of Slovak Republic, Bratislava.

Maglay J., Halouzka R., Baňacký V., Pristaš J., Janočko J., Hók J. (1999) Neotectonic map of Slovakia and explanation 1:500 000. GÚDŠ Bratislava.

Mašín J. (1963) Aeromagnetická a aerorádiometrická mapa ČSSR v měřítku 1:200000. ÚÚG Praha.

Mišík M. (1992) Pieniny Klippen Belt in relationship with Mesozoic and Tertiary volcanism. Západné Karpaty, Geológia, 16: 47-64.

Mořkovský M., Novák J., Lukášová R. (1992) Geophysical prospectings for hydrocarbons in the Intracarpathian Paleogene and in the East Slovakian Flysch belt. Sborník geologických věd, Užitá Geofyzika, 25: 9-48.

Ondra P., Hanák J. (1989) Petrofyzikálna štúdia sedimentov východoslovenského flyša. Geologicke Práce - Správy, 89: 67-89.

Oszczypko N., Golonka J., Malata T., Poprawa P., Słomka T., Uchman A. (2002) Tectono-stratigraphic evolution of the Outer Carpathian basin (Western Carpathans, Poland). Geologica Carpathica, Special Issue, 53.

Pécskay Z., Lexa J., Szakács A., Szeghedi I., Balogh K., Konečný V., Zelenka T., Kovacs M., Póka T., Fülöp A., Márton E., Panaiotu C., Cvetković V. (2006) Geochronology of Neogene magmatism in the Carpathian arc and intra-Carpathian area. Geologica Carpathica, 57 (6): 511-530.

Pécskay Z., Seghedi I., Kovacs M., Szakacs A., Fülöp A. (2009) Geochronology of the Neogene calc-alkaline intrusive magmatism in the "Subvolcanic Zone" of the Eastern Carpathians (Romania). Geologica Carpathica, 60 (2): 181-190.

Plašienka D., Grecula P., Putiš M., Kováč M., Hovorka D. (1997) Evolution and structure of the Western Carpathians: an overview. In: Geological Evolution of the Western Carpathians (eds. P. Grecula, D. Hovorka and M. Putiš): 7-24. Mineralia Slovaca Monograph, Bratislava.

Planke S., Svensen H., Hovland M., Banks D.A., Jamtveit B. (2003) Mud and fluid migration in active mud volcanoes in Azerbaijan. Geo-Marine Letters, 23: 258-268.

Poprawa D., Nemčok J., eds. (1988-1989) Geological atlas of the Western Outer Carpathians. Scale 1:500 000. Wydawnictwa Geologiczne, Warszawa.

Pospíšil L., Ádám A. (2006) Review of the Crust - Lithosphere research in the Carpathians. AAPG Memoir, 84: 481-495.

Rudinec R. (1989) Crude oil, natural gas and geothermal energy resources in eastern Slovakia. ALFA publishing, Bratislava.

Ryłko W., Tomaś A. (1995) Morphology of the consolidated basement of the Polish Carpathians in the light of magnetotelluric data. Geological Quarterly, 39 (1): 1-16.

Shinohara H. (2008) Excess degassing from volcanoes and its role on eruptive and intrusive activity. Reviews of Geophysics, 46: $1-31$.

Ślączka A. (1970) Geology of the Dukla Unit (in Polish with English summary). Prace Instytutu Geologicznego, 63: 1-97. 
Ślączka A., Kruglov S., Golonka J., Oszczypko N., Popadyuk I. (2006) The general geology of the Outer Carpathians, Poland, Slovakia and Ukraine. AAPG Memoir, 84: 1-70.

Sparks R.S.J. (2003) Forecast volcanic eruption. Earth and Planetary Science Letters, 210: 1-15.

Stanica M., Stanica D., Marin-Furnica C. (1999) The placement of the Trans/European Suture Zone on the Romanian territory by electromagnetic arguments. Earth Planets Space, 51: 1073-1078.

Stefaniuk M. (2006) Some results of a new magnetotelluric survey in the area of the Polish Outer Carpathians. AAPG Memoir, 84: 707-716.

Svensen H., Planke S., Malthe-Sorenssen A., Jamtveit B., Myklebust R., Eidem T.R., Rey S.S. (2004) Release of meth- ane from a volcanic basin as a mechanism for initial Eocene global warming. Nature, 429: 524-527.

Szeliga W., Michalik M. (2003) Contact metamorphism and hydrothermal alterations around andesite intrusion of the Jarmuta hill, Pieniny (Poland). Geologica Carpathica, 46: 327-334.

Tari G., Horváth F. (2006) Alpine evolution and hydrocarbon geology of the Pannonian Basin: an overview. AAPG Memoir, 84: 605-618.

Tomek Č., Švancara J., Budík L. (1979) The depth and the origin of the West Carpathian gravity low. Earth and Planetary Science Letters, 44: 39-42.

Trua T., Birkenmayer K., Serim G., Pécskay Z. (2006) Petrography and geochemistry of Middle Miocene (Sarmatian) volcanic area of the Pieniny Mts., Western Carpathians. Lithos, 90: 57-76. 